\title{
Study on Teacher-Student Relationship in Postgraduate Education
}

\author{
Qing-hua Du* \\ School of Marxism, Zhejiang University, \\ Hangzhou, Zhejiang, China \\ Email: 529679895@qq.com
}

\begin{abstract}
Against the background of graduate enrollment expansion in China's universities, what kind of relationship graduate students and tutors keep is a topic of concern. With the help of literature and logical analysis method, the author proposes that the tutor is in an absolute position of authority in the process of graduate student cultivation; there is a tendency of inequality, utilitarianism and alienation in the relationship between graduate students and tutors. To improve this condition, we should start with setting up a new educational concept, improving the management system and establishing teacher-student communication mechanism. The uniqueness of the article lies in the analysis of the teacher-student relationship in postgraduate education is based on the social and educational background of China.
\end{abstract}

Keywords-Postgraduate Education; Teacher-student Relationship; Tutor; Graduate student

Postgraduate education is the highest form of talent cultivation for higher education in China. The teacher-student relationship in postgraduate education plays an important part in affecting the quality of postgraduate education, and is a kind of mutual relationship between tutors and graduate students in teaching, research, and daily interaction. More precisely, it is a relationship system; "including the ethical, legal, managerial, psychological, and interpersonal relationships between teachers and students [1].” what is the cultivation mode of postgraduate education in China? How is the teacher-student relationship in the process of cultivating graduate students? Is there any deficiency? These issues are worthy of concern and study.

\section{General Situation of the EduCAtion and Cultivation OF Postgraduates IN CHINA}

In June 1951, China promulgated the "Decision on Reforming the Academic System", which stipulated that universities and specialized colleges set up graduate divisions. In 1953, the Ministry of Higher Education released the Interim Measures for the Cultivation of Graduate Students in Institutions of Higher Education (draft), and adopted the "tutorial system" in the Soviet Union during the course of cultivating graduate students. In 1963, the Ministry of Education passed the Interim Regulations on the Training of Graduate Students in Institutions of Higher Education, and put forward the method of combining personal guidance by tutor and collective guidance by teaching and research section in graduate cultivation. In the ensuing "The Great Proletarian
Cultural Revolution”, teachers were suppressed so the tutorial system actually ceased to function.

After 1978, as the postgraduate education in China was regularized and legalized, the tutorial system was again incorporated into the higher education system. China's graduate education adopts tutorial system under the unit system, which is very close to the "apprenticeship" tutorial system in Europe [2]. The tutor becomes the chief person in charge of postgraduate's school life with an absolute position of authority, which is clearly stipulated in many educational policies. For example, the Opinions on Deepening the Reform of Postgraduate Education issued by the Ministry of Education in 2013 states that the tutor is the first person responsible for graduate cultivation, having the responsibility to teach graduate students frontiers of disciplines, research methods, and academic norms.

\section{Main Problems Existing In the Teacher-Student RELATIONSHIP IN PostgRadUATE EdUCATION}

Postgraduate education helps train a large number of high-level talents for China. Although the relationship between tutors and students is overall harmonious, some problems are inevitable. Such as:

\section{A The Tendency of Inequality of Teacher-Student Relationship}

During the cultivation process, graduate students and tutors are in an unequal status. Whether the graduate students can pass the mid-term assessment, whether they have the qualifications for thesis defense, etc., are totally determined by the tutors. Moreover, management departments and universities have given a rather vague definition of job responsibilities and job rights of tutors and lack specific institutional constraints on the evaluation and supervision of them, making it difficult to determine the boundary between teachers and students. If the tutor is of good quality, graduate students may be well-educated in academic literacy and character. While the tutor with poor quality will have a bad effect on students, which can sometimes bring terrible consequence.

\section{$B$ The Tendency of Utilitarianism of Teacher-Student Relationship}

The relationship between tutors and graduate students, established on the basis of academic logic, is an educational relationship, in essence, an academic social relationship, which not only embodies the academic interaction between teachers and students based on knowledge transfer, but also covers 
spiritual communication and moral education [3]. However, during the actual cultivation process, some tutors, especially those of science and engineering majors, incorporate graduate students into profitable R\&D activities. Thus their relationship was dissociated into an employment relationship, with postgraduates often referring to their tutors as "bosses". Such situation has drained student's energy to study and conduct research practices and hindered the development of their research capabilities and innovation capabilities.

\section{The Tendency of Alienation of Teacher-Student Relationship}

After 2001, China's graduate enrollment keeps enlarging. According to the objectives set out in the "National Medium and Long-term Education Reform and Development Plan Outline (2010-2020)", by 2020, the number of graduate students will reach 2 million. In stark contrast to the rapid increase in the number of students, there is a limited increase in the number of postgraduate tutors. Due to the lack of time and energy, postgraduate tutors often have to shorten the time spent communicating with each graduate student. Such situation is even worse for tutors who shoulder educational and teaching tasks and administrative responsibility. At the same time, the exchanges between teachers and students in the current postgraduate cultivating process focus mainly on academic development, apart from which, tutors often have little understanding of postgraduates' outlook on life, living conditions, and personal thoughts. All these factors lead to the lack of exchange of thoughts and feelings between teachers and students.

\section{Suggestions FOR Optimizing TeACHER-STUDENT RELATIONSHIP IN POSTGRADUATE EDUCATION}

In response to the problems existing in the above-mentioned teacher-student relationship in postgraduate education, and for the improvement and optimization of the teacher-student relationship, the following recommendations are hereby proposed:

\section{A Set up a New Educational Concept}

As the two main bodies in the graduate training process, postgraduates and tutors should be completely equal in their personality merely with different responsibilities and missions. It's a two-way relationship. Just as there will be no teachers without students, there will be no students without teachers [4]. Moreover, in the specific educational scene of teacher-student interaction, students often become "non-educators" and may actually act as "educators". In this sense, the static relation of teaching by teacher and learning by students should be converted into the dynamic relation of mutual learning of teachers and students [5]. Therefore, in the process of graduate cultivation, with new-established educational concept, we must not only respect the actual authority of the tutors, but also break the authoritative monopoly of them, and strive to create an equal and free teacher-student relationship.

\section{B Improve Management System}

For the fact that the rules and regulations regarding postgraduate education are often too general and formal, the management system should be improved and refined. The improvement of rules and regulations ensures that every possible occurrence during the cultivation has rules to follow and equip postgraduates and tutors with rule consciousness. Specifically, it mainly includes the following aspects: First, establish a strict tutor selection mechanism. When selecting postgraduate tutors, not only should their teaching abilities, scientific research quality be examined, but also their moral quality should be paid great attention to. Second, establish a scientific tutor evaluation mechanism. We must urge tutor to perform their duties seriously during the graduate cultivation process through multiparty (including graduate students) assessment, and incorporate such evaluation into appraisal mechanism for tutors. Third, reinforce feasible tutor supervision mechanism. Colleges and universities should pay great attention to the specific implementation of the cultivation process and establish an effective feedback mechanism for postgraduate education. Both parties can make use of feedback to safeguard their legitimate rights and interests.

\section{Establish Teacher-Student Communication Mechanism}

The establishment of a good teacher-student relationship needs communication between the two parties, while effective communication requires not only the willingness of both parties but also a better institution. Educational administrations and universities should establish effective protection mechanisms for teacher-student communication. First of all, on account of the imbalance of teacher-student ratio in the process of postgraduate cultivation, the competent education departments should adjust the enrollment amount, professional structure, and geographical distribution of graduate students in a timely manner, achieving relative balance of graduate student's enrollment and university's nurturing capability. Secondly, the exchanges between tutors and students should be institutionalized, which ensures the regularity of communication between tutors and students, requires that the tutor should not refuse the student's visit without reason and supervises tutors through work records, student reports, etc., to develop a regular exchange habits between teachers and students. Third, we must establish a conflict resolution mechanism between tutors and students to ensure that students have practical ways to safeguard their rights and interests when facing problems that are not conducive to their own development.

What should be noted is that although the tutor plays the most important part in shaping the relationship between graduate students and teachers, in reality, the graduate student's desire for knowledge, attitude and ability to learning also affect the development of teacher-student relationship. Therefore, to improve the teacher-student relationship, apart from optimizing the management system and the quality of tutors, graduate students should also take an initiate to make dialogues and exchanges with tutors.

\section{CONCLUSION}

In short, in the present postgraduate training model in China, tutors have absolute authority. Under the comprehensive influence of the social environment where economic interest comes first and the enlarged enrollment policy of postgraduate, teacher-student relationship has a tendency of inequality, utilitarianism, and alienation. To this end, we should start with setting up a new educational concept, improving the management system and establishing 
teacher-student communication mechanism so as to form a harmonious teacher-student relationship.

\section{REFERENCES}

[1] Jun Feng, Qing Li, "Ethical and Legal Rationally: Exploration of Relationship Between Tutors and Graduate Students", Research in Teaching, July 2016, pp.31-34. (In Chinese)
[2] Zhi-hui Fan, Jie Ma, "Rethinking Present Alienation of Postgraduate Relations". Education and Vocation, July 2010, p.170. (In Chinese)

[3] Yan-hua Wang, "From Instrumental Rationality to Communication Rationality: An Analysis of Supervisor-Postgraduate Relationship", Journal of Postgraduate Education, February 2018, pp.60-66. (In Chinese)

[4] Mercer. B\& Cocey. H.C., "Theoretical Framework in the Sociology of Education”, Cambridge: Schenkman Pub. Co, 1980, p69.

[5] Kang-ning Wu, “Are Students Merely Education Receivers?", Educational Research, 2003(4), pp.43-47. (In Chinese) 